\title{
ANALISIS KEBIJAKAN PERUMUSAN SANKSI PIDANA DENDA DALAM KUHP
}

\author{
Eka Juarsa \\ Fakultas Hukum Universitas Islam Bandung \\ Jalan Rangggading no.8 Kota Bandung Jawa Barat \\ E-mail: ekafhunisba@gmail.com
}

\begin{abstract}
The writing of this journal is motivated by aspects of criminal law policy, the phenomenon of criminal use of deprivation of liberty (imprisonment) that seems "wasteful", of course it is very contrary to the trends that are sweeping the international world today, namely to avoid imprisonment by applying selective policies as far as possible and limitative. Thus it is natural that criminal penalties are the center of attention, both are used as a substitute for short imprisonment and also as an independent sanction, because in addition to being one type of criminal sanction that is non-custodial, it is also considered not to cause stigmatization and prisonization and economically the state gets input in the form of money or at least saves social costs compared to the type of imprisonment. Then the question arises in identifying problems about how the criminal penalty system policy in the Criminal Code? The results of the study explain the determination of criminal penalties of fines formulated by adopting Alternative Systems and Single Systems. The logical consequence of this policy is that the operation of criminal penalties can only be used as an independent sanction without the possibility to operate cumulatively with other types of principal crimes. Determination of the threat of the amount / size of criminal fines is formulated by adhering to the General and Special Maximum Minimum System.
\end{abstract}

Keywords: policies, criminal penalties, sanctions

\begin{abstract}
Abstrak
Penulisan jurnal ini dilatarbelakangi dari aspek kebijakan hukum pidana fenomena penggunaan pidana perampasan kemerdekaan (penjara) yang terkesan "boros", sudah barang tentu sangat bertentangan dengan kecenderungan yang sedang melanda dunia internasional dewasa ini, yaitu untuk sejauh mungkin menghindari penjatuhan pidana penjara dengan menerapkan kebijakan selektif dan limitatif. Dengan demikian wajar apabila pidana denda menjadi pusat perhatian, baik itu digunakan sebagai pengganti pidana penjara pendek dan juga sebagai pidana yang berdiri sendiri (independendent sanction), karena selain merupakan salah satu jenis sanksi pidana yang bersifat non-custodial, juga dianggap tidak menimbulkan stigmatisasi dan prisonisasi serta secara ekonomis Negara mendapat masukan berupa uang atau setidak-tidaknya menghemat biaya sosial dibandingkan dengan jenis pidana penjara. Maka muncul pertanyaan dalam identifikasi permasalahan tentang bagaimana kebijakan sistem pidana denda di dalam KUHP? Hasil penelitian menerangkan penetapan ancaman pidana denda dirumuskan dengan menganut Sistem Alternatif dan Sistem Tunggal. Konsekuensi logis dari kebijakan ini, maka pengoperasionalan pidana denda hanya dapat difungsikan sebagai jenis sanksi yang berdiri sendiri (independent sanction) saja tanpa dimungkinkan untuk mengoperasionalkan secara kumulatif dengan jenis pidana pokok lain. Penetapan ancaman jumlah/ukuran pidana denda dirumuskan dengan menganut Sistem Minimum Umum dan Maksimum Khusus.
\end{abstract}


Kata Kunci: kebijakan, pidana denda, sanksi

\section{LATAR BELAKANG MASALAH}

Indonesia termasuk negara yang sangat lamban melakukan perubahan hukum nasionalnya. Di bidang hukum pidana, KUHP merupakan warisan produk kolonial yang paling banyak dibicarakan dan menjadi sorotan, karena sangat kuno dan ketinggalan jaman. Oleh karena itu, mengupayakan terbentuknya KUHP nasional dalam rangka pembaharuan Hukum Pidana yang berakar pada nilainilai sosial budaya masyarakat menjadi sangat urgen. Secara ilmiah terdapat beberapa ahli yang telah membahas dan menguraikan tentang pembaharuan hukum pidana. Para ahli hukum yang selama ini dikenal antara lain, yaitu : Sudarto ${ }^{1}$, J. E. Sahetapy $^{2}$, Bambang Purnomo ${ }^{3}$, Roeslan Saleh $^{4}$, Moeljatno ${ }^{5}$, Oemar Seno Adji ${ }^{6}$, Muladi $^{7}$, Barda Nawawi Arief ${ }^{8}$.

\footnotetext{
1 Sudarto, Suatu Dilemma Dalam Pembaharuan Sistem Pidana Indonesia (Pidato Pengukuhan Penerimaaan Guru Besar Pada Fakultas Hukum UNDIP Semarang Pada Hari Sabtu tanggal 21 Desember 1974), dalam Soekotjo Hardiwinoto (Ed), Kumpulan Pidato Pengukuhan Penerimaan Guru Besar UNDIP Semarang, Badan Penerbit Universitas Diponegoro, Semarang, 1995.

2 J.E. Sahetapy, Suatu Studi Khusus Mengenai Ancaman Pidana Mati Terhadap Pembunuhan Berencana, Rajawali Pers, Jakarta, 1982.

${ }^{3}$ Bambang Purnomo, Pelaksanaan Pidana Penjara Dengan Sistem Pemasyarakatan, Liberty, Yogyakarta, 1982.

${ }^{4}$ Roeslan Saleh, Suatu Reorientasi Dalam Hukum Pidana, Aksara Baru, Jakarta, 1983.
}

Bahkan di tingkat internasional, dalam konggres-konggres PBB mengenai The Prevention of Crime and The Treatment of Offenders sering dinyatakan dan disinyalir, bahwa sistem hukum pidana yang ada sekarang ini di beberapa negara yang berasal (dimport) dari hukum asing semasa zaman kolonial pada umumnya sudah usang dan tidak adil (obsolete and unjust) serta sudah ketinggalan zaman dan tidak sesuai dengan kenyataan (Outmoded and unreal) . Alasannya, karena sistem hukum pidana di beberapa negara yang berasal/diimpor dari hukum asing semasa zaman kolonial, tidak berakar pada nilainilai budaya dan bahkan ada diskrepansi dengan aspirasi rakyat serta tidak responsip terhadap kebutuhan sosial masa kini. Kondisi demikian oleh konggres. PBB dinyatakan sebagai faktor kriminogen, karena mengabaikan nilainilai moral dan kultural di bidang

5 Moeljatno, Atas Dasar Atau Asas-Asas Apakah Hendaknya Hukum Pidana Kita Dibangun ? (Prasaran) dalam Moeljatno , Fungsi Dan Tujuan Hukum Pidana Indonesia Dan Recana UndangUndang Tentang Asas-Asas dan Dasar-Dasar Pokok Tata Hukum Indonesia, Bina Aksara, Jakarta, 1985.

6 Oemar Seno Adji, Hukum Pidana Pengembangan, Erlangga, Jakarta, 1985.

7 Muladi, Lembaga Pidana Bersyarat, Alumni, Bandung, 1992

$\begin{array}{lllr}8 & \text { Barda } & \text { Nawawi Arief, } & \text { Kebijakan } \\ \text { Legislatif Dalam } & \text { Penanggulangan } & \text { Kejahatan } \\ \text { Dengan Pidana } & \text { Penjara, Badan } & \text { Penertbit } \\ \text { Universitas Diponegoro, Semarang, } 2000 & \end{array}$


pembangunan (termasuk di bidang hukum). ${ }^{9}$

Terlepas dari berbagai pendapat mengenai urgensi pembaharuan Hukum pidana (KUHP), secara mencolok dengan mudah dapat ditunjukkan pada ancaman sanksi pidana denda di dalam KUHP yang dinilai sudah sangat tidak sesuai dengan kebutuhan saat sekarang, baik dilihat dari segi perkembangan nilai mata uang maupun dari segi tujuan pemidanaan; dan terlebih lagi pidana (Stelsel Pidana) dalam suatu KUHP adalah cerminan dari peradaban suatu bangsa.

Sehubungan dengan hal itu, sangat menarik mengingat kembali apa yang pernah dikemukakan oleh Muladi bahwa "menerapkan hukum pidana yang diciptakan lebih dari seratus tahun yang lalu secara yuridis dogmatis dalam kontek sosial sekarang jelas akan memberikan 'citra buruk' bagi sistem peradilan pidana". ${ }^{10}$ Pernyataan tersebut ada relevansinya dengan praktek di pengadilan dewasa ini, pidana denda merupakan jenis pidana yang sangat jarang dijatuhkan, karena hakim cenderung mengoperasionalkan pidana perampasan

9 Barda Nawawi Arief, Beberapa Aspek Kebijakan Penegakan dan Pengembangan Hukum, PT. Citra Aditya Bakti, Bandung, 1998, hal.103.

${ }^{10}$ Muladi, Kapita Selekta Sistem Peradilan Pidana, Badan Penerbit Universitas Diponegoro, Semarang, 1995, hal. 4 kemerdekaan (penjara) sebagai jenis pidana "primadona" dalam putusannya. ${ }^{11}$

Dari aspek kebijakan hukum pidana fenomena penggunaan pidana perampasan kemerdekaan (penjara) yang terkesan "boros", sudah barang tentu sangat bertentangan dengan kecenderungan yang sedang melanda dunia internasional dewasa ini, yaitu untuk sejauh mungkin menghindari penjatuhan pidana penjara dengan menerapkan kebijakan selektif dan limitatif $^{12}$, sebagai akibat semakin menguatnya kritik dan soroton tajam terhadap penggunaan pidana penjara.

Pararel dengan itu, berkembangnya Aliran Modern dalam Hukum Pidana yang menitik beratkan (berorientasi) pada si pembuat (pelaku tindak pidana)

11 Berdasarkan hasil penelitian yang dilakukan Barda Nawawi Arief, terhadap putusan Pengadilan Negeri di seluruh Indonesia mengenai perkara kejahatan dalam tahun 1973 sampai tahun 1982, dapat diketahui bahwa dari 434.3133 terdakwa yang Pengadilan Negeri di seluruh Indonesia terdapat 355.456 terdakwa atau sekitar $81,84 \%$ yang dijatuhi pidana penjara. Jumlah ini merupakan yang paling banyak dijatuhkan; untuk jenis pidana lainnya berada di bawah $9 \%$.(Lihat: Barda Nawawi Arief, Kebijakan Legislatif Dalam Penanggulangan Kejahatan Dengan Pidana Penjara, Op.cit. hal. 153).

12 Menurut Barda Nawawi Arief, "Kebijakan yang selektif dan limitatif dalam penggunaan pidana penjara, tidak hanya berarti harus ada penghematan dan pembatasan pidana penjara yang dirumuskan/diancamkan dalam perundang-undangan, tetapi juga harus ada peluang bagi hakim untuk menerapkan pidana penjara itu secara selektif dan limitatif. Ini berarti harus pula tersedia jenis/tindakan alternatif lain yang bersifat "non-custodial". (Lihat Barda Nawawi Arief, Bunga Rampai Kebijakan Hukum Pidana, PT. Citra Aditya Bakti, Bandung, 2002, hal. 234-235 ) 
menghendaki individualisasi pidana, artinya pemidanaan memperhatikan sifatsifat dan keadaan si pembuat. ${ }^{13}$ Sebagai konsekuensinya maka menuntut pengembangan lebih banyak jenis-jenis sanksi pidana non-custodial dalam stelsel pidana yang ada di dalam KUHP.

Dengan demikian wajar apabila pidana denda menjadi pusat perhatian, baik itu digunakan sebagai pengganti pidana penjara pendek dan juga sebagai pidana yang berdiri sendiri (independendent sanction), karena selain merupakan salah satu jenis sanksi pidana yang bersifat non-custodial, juga dianggap tidak menimbulkan stigmatisasi dan prisonisasi serta secara ekonomis Negara mendapat masukan berupa uang atau setidak-tidaknya menghemat biaya sosial dibandingkan dengan jenis pidana penjara.

Terlebih lagi berdasarkan beberapa hasil penelitian di luar negeri maupun di dalam negeri, ${ }^{14}$ yaitu antara lain yang dilakukan oleh Roger Hood, Hall Williams, R.M. Jackson, dan Sudarto yang secara umum diungkapkan bahwa ada tanda-tanda pidana denda lebih berhasil

${ }^{13}$ Sudarto, Kapita Selekta Hukum Pidana, Alumni, Bandung, 1986, hal. 80

14 Menurut Sudarto, Bahwa " hasil penelitian di negara lain sangat bermanfaat sebagai bahan perbandingan dan akan membantu pula untuk penyelesaian di negara tertentu" (Sudarto, Ibid, hal. 85-86) atau lebih efektif dari pada pidana penjara atau kurungan. ${ }^{15}$

Dalam era global seperti sekarang ini, yang ditandai adanya kemajuan di bidang transportasi, dan komunikasi modern, berimbas pada berkembangnya kualitas tindak pidana. Serta diakuinya korporasi sebagai subjek hukum pidana dalam kejahatan yang dilakukan oleh korporasi (corporate crimes), maka eksistensi sanksi pidana denda pun mutlak diperlukan.

Oleh karena itu wajar, apabila dalam rangka politik kriminal sanksi pidana denda semakin menempati posisi yang strategis sebagai salah satu tulang punggung (sarana) untuk memberantas tindak pidana. Hal demikian dapat dilihat secara signifikan maraknya penggunaan pidana denda sebagai salah satu jenis sanksi pidana yang dilibatkan dalam mengatasi masalah-masalah delik-delik baru sebagai akibat pesatnya perkembangan ekonomi maupun teknologi canggih yang diatur dalam beberapa "undang-undang pidana khusus" atau

15 Lihat: Catatan kaki no. 6 dari tulisan Barda Nawawi Arief, Dalam :Muladi dan Barda Nawawi Arief, Teori-Teori dan Kebijakan Pidana, Alumni, Bandung,1992, hal. 175; Lihat pula ibid hal.112 
perundang-undangan pidana di luar KUHP. ${ }^{16}$

Berdasarkan uraian di atas, fenomena kebijakan legislatif mengenai sanksi pidana denda yang berkorelasi dengan hukum penitensier menarik sekali untuk dikaji. Karena secara substansial, masalah yang berkaitan dengan hukum penitensier merupakan bagian penting dari pemidanaan, khususnya dalam merumuskan kebebasan yang diberikan kepada hakim dalam menentukan jenis pidana, jumlah (besarnya) serta cara pelaksanaan sanksi pidana denda. ${ }^{17}$

Ditinjau dari sudut sistem pemidanaan, kebijakan legislatif sesuai dengan fungsi yang diembannya mempunyai peran yang sangat penting, karena di sini akan ditetapkan sistem sanksi pidana dan pemidanaan yang akan

16 Menurut Sudarto, yang dimaksud dengan "undang-undang pidana khusus" adalah undang-undang pidana selain KUHP, yang merupakan induk peraturan hukum pidana. Kedudukan sentral dari KUHP ini terutama karena di dalamnya di muat ketentuan-ketentuan umum dari hukum pidana dalam Buku I, yanag berlaku juga terhadap tindak-tindak pidana yang terdapat di luar KUHP, kecuali apabila undang-undang menentukan lain (Pasal 103 KUHP); (Lihat Sudarto, Op.cit. hal. 64)

${ }^{17}$ Menurut E. Utrecht, hukum penitensier merupakan sebagian dari hukum positif yang menentukan jenis sanksi atas pelanggaran, lamanya sanksi itu dirasakan oleh pelanggar dan cara serta tempat sanksi itu dilaksanakan. Sanksi hukuman maupun tindakan merupakan suatu sistem, dan sistem inilah yang dipelajari oleh (ilmu) hukum penitensier. (Lihat : E. Utrecht, Hukum Pidana II, Pustaka Tinta Mas, Surabaya, hal. 268) mendasari dan mempermudah penerapannya maupun pelaksanaannya dalam rangka operasionalisasi pidana (denda) secara inconcreto dalam kesatuan sistem pidana denda. ${ }^{18}$

\section{RUMUSAN MASALAH}

Berdasarkan dari uraian latar belakang tersebut diatas, maka rumusan masalah yang diambil adalah bagaimana kebijakan sistem Pidana Denda di dalam KUHP?

\section{METODE PENELITIAN}

Metode penelitian ini menggunakan penelitian Hukum Normatif dan dikaji dengan menggunakan konsep, teori dan peraturan perundang-undangan yang berlaku.

\section{PEMBAHASAN}

Kebijakan Sistem Pidana Denda Didalam KUHP

Kebijakan menetapkan sanksi pidana denda di dalam KUHP maupun di luar KUHP (UU Pidana Khusus) pada hakekatnya bertujuan untuk dioperasionalkan guna menanggulangi tindak pidana.

18 Tugas-tugas legislatif (legislasi) merupakan salah satu fungsi DPR yang diatur dalam perubahan kedua UUD'45. Pasal 20A menyebutkan bahwa DPR memiliki fungsi Legislasi, fungsi anggaran, dan fungsi pengawasan. Selanjutnya , Pasal 21 menyatakan bahwa "setiap anggota Dewan punya hak mengajukan usul rancangan undang-undang" 
Membahas

kebijakan

penetapan/perumusan pidana denda dalam KUHP (WvS) tentu saja tidak dapat dilepaskan dengan masalah kebijakan penggolongan jenis tindak pidana yang ditetapkan dalam KUHP (WvS).

Berdasarkan sistematika KUHP, penggolongan jenis tindak pidana terdiri atas:

- Kejahatan (Misdrijven) dalam

Buku II, Pasal 104 - 488;

- Pelanggaran (Overtredingen)

dalam Buku III, Pasal 489 - 569.

Namun demikian, tidak dijelaskan apa yang menjadi dasar kebijakan pembuat KUHP (WvS) dalam menggolongkan suatu perbuatan sebagai kejahatan atau sebagai pelanggaran. Menurut Romly Atmasasmita, penggolongan atau pembedaan tindak pidana berupa 'kejahatan' (Misdrijven) dan pelanggaran (Overtredingen) berasal dari perbedaan antara mala in se dan mala prohibita yang dikenal dalam hukum Yunani. Mala in se adalah perbuatan yang disebut sebagai kejahatan karena menurut sifatnya adalah jahat. Sedang Mala prohibita, suatu perbuatan disebut kejahatan karena undang-undang menetapkan sebagai perbuatan yang dilarang. Pembedaan antara kejahatan dan pelanggaran tersebut semula didasarkan atas pertimbangan tentang adanya pengertian istilah rechtsdelict dan wetsdelict. ${ }^{19}$ Rechtdelict (delik hukum) berarti tanpa undangundang, tanpa putusan hakim telah dirasakan oleh masyarakat sebagai delik (kejahatan); sedangkan wetsdelict (delik undang-undang) berarti undang-undanglah yang menetapkan suatu delik termasuk pelanggaran. ${ }^{20}$ Sementara Andi Hamzah berpendapat, pembedaan delik berupa rechtsdelict dan wetsdelict adalah pembedaan dari aspek kualitatif, sebagai lawan dari pembedaan secara kuantitatif, di mana ancaman pidana terhadap kejahatan lebih berat dibanding pelanggaran. ${ }^{21}$

Beberapa akibat penting dari pembagian delik kejahatan dan pelanggaran terhadap hukum pidana positif yang dimaksud, yaitu:

a. Dalam hal kejahatan unsur sengaja atau kealpaan harus dibuktikan, sedangkan dalam pelanggaran biasanya unsur sengaja atau kealpaan itu tidak perlu dibuktikan;

b. Dalam hal pelanggaran, yang mencoba (poger) dan yang membantu (medeplichtige) tidak dapat dihukum,

19 Romly Atmasasmita, Perbandingan Hukum Pidana, Mandar Maju, Bandung, 1996, hal,49

20 Andi Hamzah, Hukum Pidana Ekonomi (Edisi Revisi Selaras Inpres No. 4 Tahun 1985) Erlangga, Jakarta, 1996, hal. 36

21 Ibid 
dalam hal kejahatan pembuat kedua delik ini dihukum.

c. Pasal 59 KUHP, mengandung ancaman terhadap pengurus dan komisaris suatu badan hukum karena disangka telah melakukan delik, hanya berlaku dalam hal pelanggaran saja.

d. Pengaduan sebagai syarat penuntutan sesuatu delik hanya ditentukan untuk perkara kejahatan saja.

e. Dalam hal concursus, maka ada pembedaan pemidanaan untuk kejahatan dan pelanggaran.

f. Dalam hal verjaring (daluwarsa) untuk melakukan penuntutan dan melaksanakan pidana, maka ditetapkan verjaring kejahatan lebih lama daripada pelanggaran.

g. Afkoop (penebusan penuntutan pidana) hanya dapat dilakukan terhadap delik pelanggaran yang diancam pidana denda saja.

h. Dalam hal delik pelanggaran dan kejahatan yang terjadi karena alpa, maka penyitaan barang sebagai hukuman tambahan hanya dapat dilakukan apabila dengan tegas diatur dalam undang-undang; sedangkan dalam hal delik kejahatan senantiasa dapat dirampas asal kepunyaan si terpidana. i. Hak (dari jaksa) untuk menuntut secara pidana terhadap seorang WNI yang melakukan delik kejahatan di luar negeri (prinsip nasional aktif).

j. Menurut Pasal 7 KUHP, aturan pidana dalam UU RI berlaku bagi pegawai negeri Indonesia yang melakukan salah satu delik kejahatan yang tersebut dalam Bab XXVIII Buku II di luar negeri.

k. Penadahan (heling) barang-barang yang diperoleh karena kejahatan saja yang dapat dihukum.

1. Aturan-aturan istimewa mengenai "turut serta" (bijzondere deelnemingsvooschriften) yang ditentukan dalam Pasal 61 dan 62 KUHP hanya berlaku bagi kejahatan saja.

m. Pembagian delik sebagai kejahatan dan pelanggaran berpengaruh pula terhadap ketentuan dalam hukum hukum acara.

Relevan dengan pendapat di atas, akhirnya penulis sependapat dengan kesimpulan yang dikemukakan oleh Barda Nawawi Arief bahwa, "penetapan kualifikasi delik" sebagai kejahatan dan pelanggaran merupakan "penetapan kualifikasi yuridis" yang mempunyai konsekuensi yuridis/konsekuensi hukum baik dalam arti yuridis-materiel (KUHP) maupun yuridis-formal (KUHAP). Di 
samping itu, pembagian delik diperlukan pula untuk "menjembatani" berlakunya Aturan Umum KUHP terhadap hal-hal yang diatur dalam UU di luar KUHP. ${ }^{22}$

Apabila dibatasi hanya di bidang yuridis-materiel maka konsekuensi yuridis/hukum yang dimaksud adalah Aturan Umum dalam Buku I KUHP seperti masalah percobaan, pembantuan, perbarengan, delik aduan, tenggang waktu penuntutan/melaksanakan pidana, pembayaran denda maksimum untuk menghindari penuntutan, 'berlaku' dan 'mengikat' ketentuan pemidanan yang dirumuskan dalam Buku II dan III KUHP; demikian pula ketentuan pemidanaan yang diatur dalam undang-undang pidana di luar KUHP, kecuali jika undang-undang tersebut menentukan lain (Pasal 103 KUHP).

Kebijakan sistem perumusan ancaman pidana denda dalam Buku II dan III di dalam KUHP, akan penulis uraikan sebagai berikut.

22 Barda Nawawi Arief, Masalah Penegakan Hukum \& Kebijakan Penanggulangan Kejahatan, Op. Cit. hal151; Barda Nawawi Arief, Pelenglap Bahan Kuliah Hukum Pidana I, Op.cit. hal 20

\begin{tabular}{|c|c|c|c|}
\hline No & $\begin{array}{l}\text { Perumusan } \\
\text { Ancaman Pidana }\end{array}$ & ท́ & $\%$ \\
\hline 1. & $\begin{array}{l}\text { Mati/Seumur } \\
\text { hidup/Penjara* }\end{array}$ & 13 & 2,21 \\
\hline 2. & $\begin{array}{l}\text { Seumur } \\
\text { Hidup/Penjara }\end{array}$ & 18 & 3,07 \\
\hline 3. & Penjara & 395 & 67,29 \\
\hline 4. & Penjara/Kurungan & 13 & 2,21 \\
\hline 5. & $\begin{array}{l}\text { Penjara/Kurungan/ } \\
\text { Denda }\end{array}$ & 18 & 3,07 \\
\hline 6. & Penjara/Denda & 118 & 20,10 \\
\hline 7. & Kurungan & 2 & 0,34 \\
\hline 8. & Kurungan/Denda & 9 & 1,54 \\
\hline 9. & Denda & 1 & 0,17 \\
\hline & Jumlah & 587 & 100 \\
\hline
\end{tabular}

Catatan:

- ฑ́ : Jumlah tindak pidana yang memuat perumusan ancaman pidana yang bersangkutan.

- * : "Penjara" maksudnya pidana penjara dalam waktu tertentu.

Lebih terperinci mengenai pasal-pasal di dalam Buku III KUHP yang memuat perumusan ancaman pidana dapat dikemukakan sebagai berikut:

1) Perumusan ancaman pidana

ท́ 'Kurungan' sqfa (Perumusan Tunggal): Pasal 492 ayat (2), 504 ayat (1), 504 ayat (2), 505 ayat (1), 505 ayat (2), 506, 5201 e, 2e; 523 
ayat (2); 536 ayat (3), ayat (4); dan 540 ayat (2).

2) Perumusan ancaman pidana 'Kurungan atau Denda' (Perumusan Alternatif): Pasal 490 1e, 2e, 3e, 4e; 492 ayat (1); 493, 500,502 ayat (1), 503 1e, 2e; 508, 508 bis, 509, 510 ayat (2), 512 a, 513, 514, 515 ayat (1) 1e, 2e; 517 ayat (1) 1e, 2e; 517 ayat (2); 518, 519 bis 1e, 2e; 521, 523 ayat (1), 528 ayat (1) 1e, 2e, 3e; 531, 532 1e, 2e, 3e; 533 1e, 2e, 3e, 4e, 5e; 534, $535,537,538,539,540$ ayat (1) $1 \mathrm{e}$, 2e, 3e, 4e, 5e; 542 ayat (1) 1e, 2e; 544 ayat (1) dan (2); 545 ayat (1), (2); 546 1e,2e; 547, 554, 555, 565, 566.

3) Perumusan ancaman pidana 'Denda' saja (Perumusan Tunggal: Pasal 489 ayat (1); 491 1e, 2e; 494 1e, 2e, 3e, 4e, 5e, 6e; 495 ayat (1), 496, 497 ayat (1) dan (2); 501 ayat (1)1e, 2e, ; 507 1e, 2e, 3e; 510 ayat (1) $1 \mathrm{e}, 2 \mathrm{e} ; 511,512$ ayat (1), ayat (2), 516 ayat (1); 519 ayat (1); 522; 524 1e, 2e, 3e; 525 ayat (1), (2); 526; 529, 530 ayat (1); 536 ayat (1), 541 ayat (1) 1e, 2e, 3e; 548, 549 ayat (1); 550; 551; 552; 556; 557 1e, 2e; 557 1e, 2e; 558; 558a; $5591 \mathrm{e}, 2 \mathrm{e} ; 560 ; 561 ; 562$ ayat (1) 1e, 2e, 3e, 4e; 563; 564; 567; 568 dan 569.ayat (1), (2).

Berdasarkan uraian perumusan ancaman pidana yang termuat di dalam Buku II dan Buku III KUHP, maka secara keseluruhan di dalam KUHP terdapat 722 pola perumusan ancaman pidana, baik untuk tindak pidana kejahatan maupun pelanggaran dengan variasi pola perumusan: M/SH/P (13 perumusan atau $1,80 \%), \mathrm{SH} / \mathrm{P}$ (18 perumusan atau $2,49 \%$ ), $\mathrm{P}$ (395 perumusan atau 54,71\%),P/K (13 perumusan atau 1,80\%), P/K/D (18 perumusan atau 2,49\%),P/D (118 perumusan atau $16,35 \%), \mathrm{K}$ (14 perumusan atau $1,94 \%), \mathrm{K} / \mathrm{D}$ (71 perumusan atau $9,83 \%$ ) dan D (62 perumusan atau $8,59 \%$ ). Selanjutnya, dalam 722 perumusan ancaman pidana tersebut terdapat komposisi jenis ancaman pidana sebanyak 1004 yang terdiri atas: pidana mati sebanyak $13(1,30 \%)$; pidana penjara sebanyak 606 (60,36\%); pidana kurungan sebanyak 116 (11,55\%); dan pidana denda sebanyak $269(26,79 \%)$.

Mencermati sistem pengancaman pidana denda di atas, jelas KUHP tidak menganut Sistem Kumulasi. Dengan demikian, tertutup kemungkinan pemidanaan secara kumulatif baik pidana mati dan denda maupun pidana perampasan kemerdekaan dan denda. 
Sebaliknya dengan mencermati perkembangan kualitas maupun kuantitas kejahatan, utamanya dengan motif ekonomi, maka menurut penulis perlu perluasan sistem pengancaman pidana denda sehingga memungkinkan pemidanan pidana denda secara kumulatif dengan jenis pidana perampasan kemerdekaan. Kebijakan tersebut tidak saja dibutuhkan sebagai upaya antisipasi/strategi dalam menindak tindak pidana dengan motif ekonomi; tetapi sekaligus merupakan langkah kebijakan untuk meningkatkan fungsi pidana denda itu sendiri. Melalui perumusan kumulasi, pidana denda dapat difungsikan sebagai pemberatan pidana sekaligus merampas kembali keuntungan hasil tindak pidana. Sebagai misal, apabila kebijakan ini (pemidanaan secara kumulatif) diterapkan dalam KUHP, maka dapat diancamkan terhadap kejahatan maupun pelanggaran yang berhubungan dengan kekayaan orang, seperti yang diatur dalam:

1. Titel XXII Buku II tentang Pencurian;

2. Titel XXIII Buku II tentang Pemerasan dan Pengancaman;

3. Titel XXIV Buku II tentang Penggelapan Barang;

4. Titel XXV Buku II tentang Penipuan;
5. Titel XXVI Buku II tentang Merugikan Orang Berpiutang dan Berhak;

6. Titel XXVII Buku II tentang Penghancuran atau Perusakan Barang;

7. Titel XXX Buku II tentang Pemudahan; dan

8. Titel VII Buku III tentang Pelanggaran-Pelanggaran tentang Tanah-Tanah Tanaman.

Alasannya, kedelapan macam tindak pidana di atas, merupakan jenis tindak pidana yang dapat menimbulkan kerugian terhadap kekayaan korban di satu sisi, dan mendatangkan keuntungan di pihak pelaku di sisi lain.

Menelusuri persoalan mengapa kumulatif pidana pokok tidak dimungkinkan dalam Sistem KUHP, kiranya dapat dijelaskan dengan pendekatan dari segi historis.

KUHP yang berlaku sekarang ini adalah warisan kolonial Belanda. Terkait hal ini menurut Barda Nawawi Arief, apabila merujuk pengelompokan keluarga hukum (legal families) yang dilakukan oleh Rene David254, maka KUHP warisan ini termasuk keluarga/sistem hukum kontinental (Civil Law System) atau sering disebut The Romano-Germanic Family, dengan ajaran yang menonjolkan paham 
individualism, libelalism right ${ }^{23}$ dan salah satu doktrinnya tercermin dalam sistem pemidanaannya yang menganut sistem alternatif dan alternatif-kumulatif, dengan batas minimum dan maksimum ancaman pidana yang diperkenankan menurut undang-undang. ${ }^{24}$

Namun sangat disayangkan, di antara kedua sistem, yakni Sistem Alternatif dan Sistem Alternatif-kumulatif, hanya Sistem Alternatif yang diadopsi (bahkan mendominasi) sistem pengancaman pidana dalam KUHP sehingga tertutup peluang untuk menerapkan pemidanaan secara kumulatif dua pidana pokok, sebagaimana hal itu diterapkan oleh pada umumnya keluarga hokum yang menganut sistem CammonLaw Family.

\section{PENUTUP}

\section{Kesimpulan}

Kebijakan Sistem Pidana Denda dalam KUHP

1. Penetapan ancaman pidana denda dirumuskan dengan menganut Sistem Alternatif dan Sistem

${ }^{23}$ Barda Nawawi Arief, Beberapa Aspek Pengembangan Ilmu Hukum Pidana (Menyongsong Generasi Baru Hukum Pidana Indonesia) (Pidato Pengukuhan Guru Besar Pada Fakultas Hukum UNDIP -Semarang pada tanggal 25 Juni 1994), Op.cit, hal. 360

24 Romly Atmasasmita.Perbandingan Hukum Pidana, Op.cit., hal. 50.
Tunggal. Konsekuensi logis dari kebijakan ini, maka pengoperasionalan pidana denda hanya dapat difungsikan sebagai jenis sanksi yang berdiri sendiri (independent sanction) saja tanpa dimungkinkan untuk mengoperasionalkan secara kumulatif dengan jenis pidana pokok lain (pidana mati, pidana penjara, atau pidana kurungan);

2. Penetapan ancaman jumlah/ukuran pidana denda dirumuskan dengan menganut Sistem Minimum Umum dan Maksimum Khusus. Jumlah ancaman minimum umum denda ditetapkan sebesar Rp. 25 sen (kemudian menjadi 3.75 sen): Sedangkan jumlah ancaman maksimum khusus untuk tindak pidana kualifikasi kejahatan berkisar antara $\mathrm{Rp} 900,00$ (Sembilan ratus rupiah) (dulu 60 gulden) dan Rp $150.000,00$ (Seratus lima puluh ribu rupiah) (dulu 10.000 gulden); Namun, ancaman pidana denda yang sering diancamkan ialah sebesar $\mathrm{Rp}$ 4.500,00 (empat ribu lima ratus rupiah) (dulu 500 gulden); Dan jumlah ancaman maksimum khusus pidana untuk delik pelanggaran 
berkisar antara Rp 225,- (Dua ratus dua puluh lima rupiah) (dulu 15 gulden) dan Rp 75.000,00 (Tujuh lima ribu rupiah) (dulu 500 gulden); Namun, yang terbanyak hanya diancam Rp 375,- (Tiga ratus tujuh puluh lima rupiah) (dulu 25 gulden) dan Rp 4.500,00 (Empat ribu lima ratus rupiah) (dulu 300 gulden). Secara keseluruhan dengan adanya beberapa peratuan perundangan-undangan yang melakukan perubahan pada pengancaman jumlah pidana denda, maka maksimum khusus pidana denda yang paling tinggi untuk kejahatan ialah Rp 150.000,00 (Seratus lima puluh ribu rupiah) (10.000 gulden), dan untuk pelanggaran paling banyak $\mathrm{Rp}$ 75.000,00 (Tujuh puluh lima ribu rupiah) (5000 gulden).

3. Penetapan pelaksanaan/eksekusi pidana denda ditentukan, bahwa pembayaran denda dilakukan dengan secara tunai. Namun demikian tidak ditentukan mengenai batas waktu pembayarannya; dan apabila denda tidak dibayar ditetapkan dengan diganti pidana kurungan pengganti/subsider yang lamanya sekurang-kurangnya 1 hari dan paling lama 6 bulan; Jumlah tersebut dapat dapat ditingkatkan menjadi 8 bulan apabila terdapat pemberatan yang disebabkan perbarengan tindak pidana (concursuss), pengulangan tindak pidana (recidive) atau tindak pidana yang berkaitan dengan jabatan yang ditentukan dalam Pasal 52 dan 52 a. Secara umum kebijakan penetapan Sistem Pidana Denda dalam KUHP memperlihatkan kebijakan yang sudah kuno dengan karakternya yang tidak elastis/kaku karena tidak memberi kebebasan bagi hakim dalam mengoperasionalkan jenis pidana denda, menetapkan jumlah/ukuran pidana denda serta pelaksanaan pidana denda.

\section{Saran}

Sistem Pidana Denda yang berorientasi ide individualisasi pidana, maka seyogyanya mempertimbangkan sistem pengancaman pidana denda yang lebih longgar/elastis/fleksibel; sekaligus menghindari kebijakan pengancaman pidana denda yang bersifat kaku/mengharuskan dan melakukan generalisasi pemidanaan. Adapun sistem yang seyogyanya dipertimbangkan adalah kebijakan memperbanyak Sistem Alternatif 
kumulatif atau Sistem Kumulatif-alternatif, karena: sistem perumusan ini secara substansial juga meliputi sistem perumusan tunggal, kumulatif dan alternatif; sistem perumusan kumulatif-alternatif merupakan pola sistem perumusan yang secara langsung merupakan gabungan bercirikan nuansa kepastian hukum (rechtszekerheids) dan nuansa keadilan karena hakim senatiasa diwajibkan untuk menerapkan asas subsidiaritas dan proposinalitas dalam mengopersionalkan pidana denda; dan melalui perumusan sistem Alternatif-kumulatif atau Sistem Kumulatif-Alternatif pidana denda dapat difungsikan sebagai pidana yang berdiri sendiri (independent sanction) sekaligus sebagai pemberatan pidana.

\section{DAFTAR PUSTAKA}

\section{Buku}

Andi Hamzah, Hukum Pidana Ekonomi (Edisi Revisi Selaras Inpres No. 4 Tahun 1985) Erlangga, Jakarta, 1996.

Bambang Purnomo, Pelaksanaan Pidana Penjara Dengan Sistem Pemasyarakatan, Liberty, Yogyakarta, 1982.

Barda Nawawi Arief, Kebijakan Legislatif Dalam Penanggulangan Kejahatan Dengan Pidana Penjara, Badan Penertbit Universitas Diponegoro, Semarang, 2000.

Barda Nawawi Arief, Beberapa Aspek Kebijakan Penegakan dan
Pengembangan Hukum, PT. Citra Aditya Bakti, Bandung, 1998.

E. Utrecht, Hukum Pidana II, Pustaka Tinta Mas, Surabaya.

J.E. Sahetapy, Suatu Studi Khusus Mengenai Ancaman Pidana Mati Terhadap Pembunuhan Berencana, Rajawali Pers, Jakarta, 1982.

Muladi dan Barda Nawawi Arief, TeoriTeori dan Kebijakan Pidana, Alumni, Bandung, 1992.

Muladi, Kapita Selekta Sistem Peradilan Pidana, Badan Penerbit Universitas Diponegoro, Semarang, 1995.

Muladi, Lembaga Pidana Bersyarat, Alumni, Bandung, 1992.

Oemar Seno Adji, Hukum Pidana Pengembangan, Erlangga, Jakarta, 1985.

Roeslan Saleh, Suatu Reorientasi Dalam Hukum Pidana, Aksara Baru, Jakarta, 1983.

Romly Atmasasmita, Perbandingan Hukum Pidana, Mandar Maju, Bandung, 1996.

Sudarto, Kapita Selekta Hukum Pidana, Alumni, Bandung, 1986. 
